\section{Long-Term Exposure of Sitka Spruce Seedlings to Trichloroacetic Acid}

\author{
J. NEIL CAPE, *, † NICHOLAS M. REEVES, \\ PETER SCHRÖDER, § AND \\ MATHEW R. HEAL \\ Centre for Ecology and Hydrology, Bush Estate, \\ Penicuik, Midlothian, EH26 0QB U.K., School of Chemistry, \\ University of Edinburgh, King's Buildings, West Mains Road, \\ Edinburgh EH9 3JJ, U.K., and Institute for Soil Ecology, \\ GSF National Research Center for Environment and Health, \\ Neuherberg, D-85764 Oberschleissheim, Germany
}

Trichloroacetic acid (TCA) has been implicated as an airborne pollutant responsible for adverse effects on forest health. There is considerable debate as to whether TCA observed in trees and forest soils is derived from atmos pheric deposition or from in situ production. This experiment reports the results from treating 4-year-old Sitka spruce (Picea sitchensis (B ong.) Carr) plants in a greenhouse over a growing season with TCA supplied either to the soil or to the foliage at concentrations of 10 and $100 \mathrm{ng} \mathrm{mL}^{-1}$. Similar uptake of TCA by needles was observed for both modes of treatment, with significant accumulation of TCA (300 ng $\mathrm{g}^{-1}$ dry wt) at the higher concentration. Larger concentrations in stem tissue were seen for the foliar-applied TCA (280 ng $\left.\mathrm{g}^{-1}\right)$ than for the soil-applied TCA $\left(70 \mathrm{ng} \mathrm{g}^{-1}\right)$, suggesting that direct stem uptake may be important. Six months after treatments stopped, TCA concentrations in the needles of plants exposed to $100 \mathrm{ng} \mathrm{mL}^{-1}$ TCA were still enhanced, showing that biological degradation of TCA in needles was slow over the winter. By contrast, no significant enhancement of TCA in soil could be detected in the directly treated soils even during the experiment. The protein content of needles treated with the higher concentration of TCA by either route was significantly smaller than for the controls, but there was no effect of TCA on the conjugation of 1-chloro-2,4-dinitrobenzene in roots nor on the conjugation of 1,2-dichloro-4-nitrobenzene in needles.

\section{Introduction}

Trichloroacetic acid (TCA) is a ubiquitous chemical that occurs in air, precipitation, vegetation, and soil (1). In recent years, ithas attracted theattention of environmental agencies because of claims that atmospheric sources of TCA had led to the decline of forest health in Central Europe (2). The debate has highlighted the uncertainty concerning the sources of TCA in theenvironment (3-5). There is consensus that the atmospheric source of TCA is from oxidation of chlorinated solvents, but the known emissions and atmospheric concentrations of potential precursorsand theknown gas-phase reactions leading to TCA formation are not sufficient to account for the concentrations of TCA found in

* Corresponding author telephone: (44) 131445 8533; fax: (44) 131445 3943; e-mail: jnc@ceh.ac.uk.

+ Centre for Ecology and Hydrology.

₹ University of Edinburgh.

$\S$ GSF National Research Center for Environment and Health. precipitation $(1,6,7)$. However, several studies have also shown that TCA may be both produced in soil $(8,9)$ and degraded in soil $(10,11)$. The source of the TCA that is found in the foliage of plants could therefore have two sources: direct uptake by leaves from the atmosphere or uptake by roots and transport to leaves in the transpiration stream. It has been shown that TCA can be transported from root to shoot (12) and vice versa (13). Increases in foliar concentrations ofTCA in treefoliage have been observed close to known industrial point sources (14), but the pathway could still be either direct atmospheric uptake or root uptake after deposition in rain. Laboratory experiments have exposed plants to TCA in soil and in simulated mist $(15,16)$ and shown that TCA is taken up both by roots and by foliage and is metabolized in foliage (15). Much of the atmospherically supplied TCA was retained on the surface of the Scots pine seedlings.

Whatever the pathway of uptake, the motivation for these experiments and field measurements was the postulated link between TCA and plant health. Some field studies showed correlations between leaf loss in conifers and birch trees and TCA concentrations $(17,18)$, but others have shown none in conifers and lichens (19). Experiments to investigate direct effects of TCA on trees have confirmed that TCA affects the production of leaf surface waxes in Eucalyptus species and may influence the control of water loss through leaves (20). At exposure levels closer to those observed in the environment, effects of TCA on pine (Pinus sylvestris L.) seedlings have been shown in terms of nitrogen metabolism (12) and changes in xenobiotic detoxification enzymes such as peroxidases and glutathione S-transferase (15). Different responses were seen in pine seedlings exposed via the atmosphere or via the roots $(16,21)$.

This experiment was designed to investigate the uptake and effects on young spruce trees when TCA was applied to the foliage only or to the soil at concentrations closer to those observed in the environment than used previously. Treatments were applied regularly throughout the growing season.

\section{Materials and Methods}

Four-year-old seedlings of Sitka spruce (Picea sitchensis (Bong.) Carr) of Queen Charlotte Island provenance were potted into a peat/loam/grit mixture (3:1:1 by volume) in 20 $\mathrm{cm}$ diameter pots and placed in an unheated greenhouse at Bush Estate, Scotland $\left(55^{\circ} 52^{\prime} \mathrm{N}, 3^{\circ} 12^{\prime} \mathrm{W}\right)$. Pots were placed on plastic saucers. I rrigation was provided to all plants equally as required using tap water supplied to the saucers. At the start of the experiment, all 120 plants were ranked by height and divided into six treatment groups of 20 trees, each group made up of four blocks of five trees, where the four blocks were stratified by height, block 1 being the tallest and block 4 being the smallest.

The plants were exposed to TCA between May 7, 1999, and October 8, 1999, on 47 occasions. The six different treatments were applied to either the soil surfaceor thefoliage (Table 1); the soil surface of all pots was lightly covered with a cardboard disk to prevent foliar-applied treatments from entering thesoil directly. Foliar applications weremadeusing a hand-held sprayer; each block of five trees was removed to a spraying area (to avoid drift) and treated with $315 \mathrm{~mL}$ of solution. For the soil treatment $63 \mathrm{~mL}$ of solution was added to the soil surface of each pot. Control treatments were applied using the same water as used to dilute a stock solution of TCA $\left(2.5 \mu \mathrm{g} \mathrm{mL}^{-1}\right)$ to the required treatment concentrations of 10 or $100 \mathrm{ng} \mathrm{mL}^{-1}$. The treatment volume 
TABLE 1. Treatments Applied to Spruce Seedlings, Twice Weekly, between May and October

$$
\begin{array}{cc}
\begin{array}{c}
\text { TCA concn } \\
\text { (ng mL }
\end{array} & \text { soil application } \\
\left(\mathrm{mL} \mathrm{plant}^{-1}\right)
\end{array}
$$

foliar application ${ }^{a}$ ( $\mathrm{mL}^{\text {plant }}{ }^{-1}$ )

control

low dose

high dose
63

63

63
63

63

63 a Maximum: assumes $100 \%$ capture by seedling foliage.

per application corresponded to the amount of water that could be retained by the canopy before significant drip occurred.

Current-year (1999) needles were sampled in August 1999 (control and $100 \mathrm{ng} \mathrm{mL}^{-1}$ only), in October 1999 at the end of the experiment $10 \mathrm{~d}$ after the last treatment, and in May 2000 after a winter without further treatment and after bud burst. A current-year shoot was removed from each tree, thoroughly rinsed with deionized water, and blotted dry. Needles were removed from thestems by plunging the shoot into liquid nitrogen. Needles were then pooled across the five trees for each height class by treatment and stored frozen at $-18^{\circ} \mathrm{C}$ prior to analysis. Stem material was also sampled in October 1999.

Chemical analysis used automated headspace gas chromatography (Perkin-Elmer HS40XL) with electron capture detection following thermal decarboxylation of TCA to give $\mathrm{CHCl}_{3}$ (22). Samples of $0.5 \mathrm{~g}$ (fresh wt) of needles from each height class and treatment wereground under liquid nitrogen using a pestle and mortar and placed into cleaned $20-\mathrm{mL}$ glass vials to which $1 \mathrm{~mL}$ of HPLC-grade water (previously degassed using oxygen-free nitrogen for $1 \mathrm{~h}$ to remove any $\mathrm{CHCl}_{3}$ ) was added. Vials were prepared in quadruplicate. One vial was heated to $60{ }^{\circ} \mathrm{C}$ for $10 \mathrm{~min}$ to liberate any background $\mathrm{CHCl}_{3}$ present in the needles, and then the headspace was analyzed by pressurizing the vial $(\mathrm{He}, 87 \mathrm{kPa})$ for $2 \mathrm{~min}$ before an injection time of $0.03 \mathrm{~min}$. The transfer line and injector were held at $200^{\circ} \mathrm{C}$. The DB- 624 column $(30 \mathrm{~m} \times 0.25 \mathrm{~mm} \times 1.4 \mu \mathrm{m})$ was held at $50^{\circ} \mathrm{C}$ for $6 \mathrm{~min}$, then heated at $25^{\circ} \mathrm{C} \mathrm{min}-1$ to $150{ }^{\circ} \mathrm{C}$, and held for $3 \mathrm{~min}$. The detector was maintained at $375^{\circ} \mathrm{C}$. The other three vials were heated to $100^{\circ} \mathrm{C}$ for $90 \mathrm{~min}$ to decarboxylate the TCA, followed by equilibration at $60^{\circ} \mathrm{C}$ for $10 \mathrm{~min}$ beforeheadspace analysis for $\mathrm{CHCl}_{3}$. The amount of TCA in the needles was calculated by subtracting the background $\mathrm{CHCl}_{3}$ (from the sample heated at $60^{\circ} \mathrm{C}$ ) from the amount measured after decarboxylation at $100{ }^{\circ} \mathrm{C}$. Routine calibration was made using standard aqueous solutions of TCA. Prior experiments that used standard addition of small volumes of TCA solution to needle samples showed that a partition factor (22) of 1.26 was required for the content of TCA in needlesamples relative to aqueous solution calibrations. For stems, only oneanalysis was made per treatment on a pooled sample of stem material across all height classes. The same partition factor was used as for needles. After analysis, the dry weight of each needle sample was measured after drying for $4 \mathrm{~d}$ at $60^{\circ} \mathrm{C}$.

A $10-\mathrm{cm}$ soil core ( $2 \mathrm{~cm}$ diameter) was removed from each pot after the October 1999 sampling. The five cores within each height class per treatment were pooled, sieved, and blended. Soil samples were analyzed for TCA by headspace gas chromatography, as above, but $1.00 \mathrm{~g}$ (fresh wt) of soil was used for each sample to which was added 1 $\mathrm{mL}$ of degassed HPLC-grade water. As for needle samples, vials were prepared in quadruplicate; one to act as a blank for $\mathrm{CHCl}_{3}$ in the soil, and three for analysis after decarboxylation. The partition ratio (22) for soils was determined experimentally to be 1.98, using standard additions of TCA solutions to soil samples.

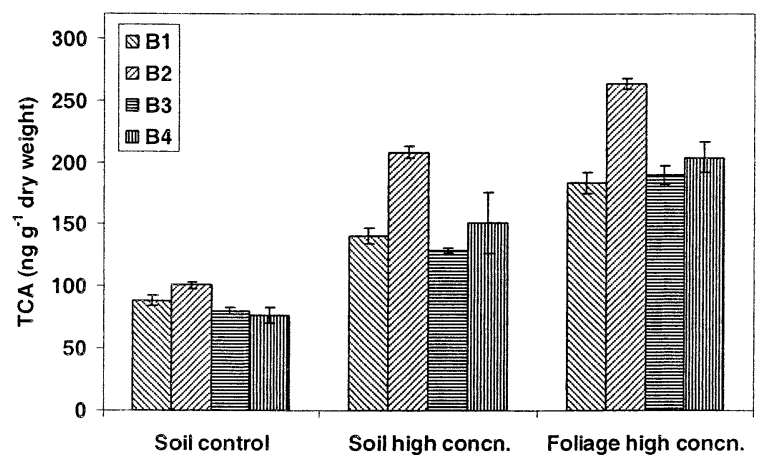

FIGURE 1. Needle content of TCA (ng $\mathrm{g}^{-1}$ dry wt) in August 1999. Error bars show the standard deviation within each block (B1-B4) of 5 plants. Treatment means were 87 (soil control), 157 (soil high concentration), and 210 (foliage high concentration) $\mathrm{ng} \mathrm{g}^{-1}$.

Plant height and root collar diameter were measured at the start of the experiment, in October 1999, and in May 2000 , and the percentage increase in height and root collar diameter were calculated. Roots and shoots were also sampled in October 1999 for enzyme analysis. Fine nonlignified root sections and current-year needles were removed, rinsed with deionized water, blotted dry, and then stored at $-80^{\circ} \mathrm{C}$ before shipping to GSF Neuherberg (Germany) for analysis of glutathione S-transferase (GST) activity. GST was analyzed on a pooled sample per treatment after grinding to a powder in liquid nitrogen, adding 10 vol of $100 \mathrm{mM}$ Tris$\mathrm{HCl}$ buffer at $\mathrm{pH}$ 7-8 containing 1\% PVP K30, 5 mM EDTA, and $0.25 \%$ Nonidet P40 (15). Theslurry was allowed to stand and was centrifuged, and the supernatant was filtered. GST in the extract was purified (23), and activity was determined spectrophometrically in triplicate using 1-chloro-2,4-dinitrobenzene (CDNB) and 1,2-dichloro-4-nitrobenzene(DCNB) as a substrate (24). Protein content was determined in duplicate (25) using bovine serum albumin as a standard.

\section{Results}

Plant Concentrations of TCA. Needles: August 1999. The needle content of TCA after 3 months is shown in Figure 1 as the mean value for the five plants in each height class. There was no systematic variation with tree height, although TCA content of treated height class 2 plants was consistently greater than for the other height classes. Needle content of TCA was significantly (ANOVA; $P<0.05$ ) greater for both treatments (soil and foliage) using $100 \mathrm{ng} \mathrm{mL}^{-1}$ solutions than for the control samples.

Needles: October 1999. The needle content of TCA at the end of the treatment period is shown for all treatments in Figure 2. Again, there was no systematic variation with plant size, and the larger concentrations seen in height class 2 in August were no longer evident. Analysis of variance for main effects of treatment concentration, treatment type (soil or foliage), and height class showed that there was a significant effect of treatment level ( $P<0.001$ ), with a significant difference between treatments at $100 \mathrm{ng} \mathrm{mL}^{-1}$ and controls and no significant effect of treatment type (foliage or soil).

Stems: October 1999. TCA concentrations in stems were generally much smaller than in needles from the same shoots (Table 2), with the exception of the foliar-applied treatment at $100 \mathrm{ng} \mathrm{mL}^{-1}$ where stem and needle concentrations were similar. The uncertainties shown in Table 2 are the standard deviations of four replicate analyses of the pooled stem material and represent analytical uncertainty rather than within-experiment error.

Needles: May 2000. TCA concentrations in the spring, 6 months after treatment ceased, were similar in the control needles to those measured in October, but concentrations 


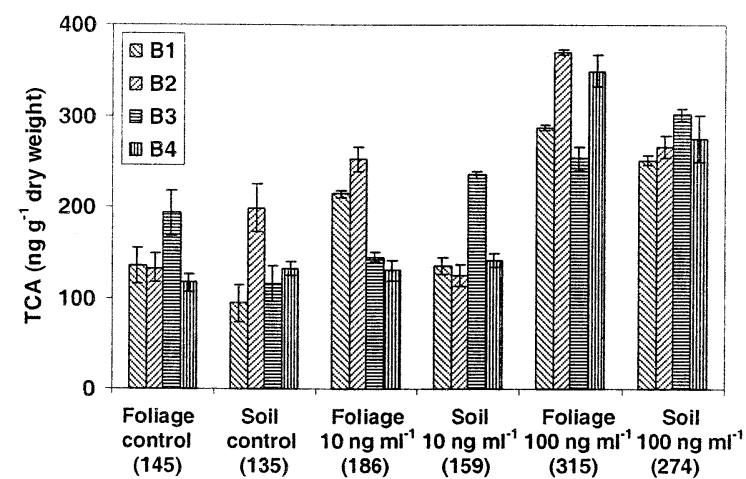

FIGURE 2. Needle content of TCA (ng $\mathbf{g}^{-1}$ dry w t) in October 1999. Error bars show the standard deviation within each block (B1-B4) of 5 plants. Treatment means are show $n$ in parentheses.

TABLE 2. Stem Content of TCA (ng $\mathrm{g}^{-1}$ dry wt) in October 1999

\begin{tabular}{llc}
\multicolumn{1}{c}{ treatment } & \multicolumn{1}{c}{ stem } & $\begin{array}{c}\text { cf. needle } \\
\text { (Figure 2) }\end{array}$ \\
control (foliage) & missing & 145 \\
control (soil) & $19 \pm 1$ & 135 \\
$10 \mathrm{ng} \mathrm{m}^{-1}$ (foliage) & $61 \pm 6$ & 186 \\
$10 \mathrm{ng} \mathrm{m}^{-1}$ (soil) & $26 \pm 4$ & 159 \\
$100 \mathrm{ng} \mathrm{mL}^{-1}$ (foliage) & $277 \pm 12$ & 315 \\
$100 \mathrm{ng} \mathrm{mL}^{-1}$ (soil) & $69 \pm 4$ & 274
\end{tabular}

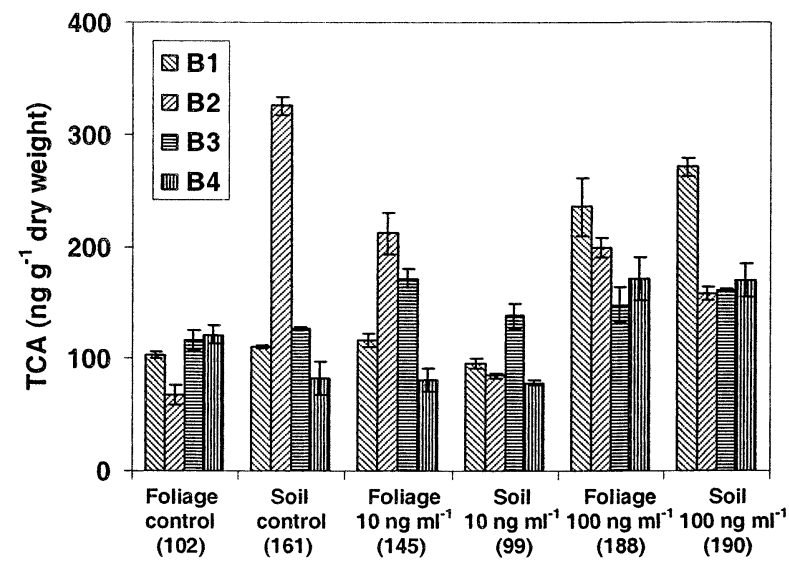

FIGURE 3. Needle content of TCA (ng g ${ }^{-1}$ dry $w \mathrm{t}$ ) in May 2000. Error bars show the standard deviation within each block (B1-B4) of 5 plants. Treatment means are show $\mathrm{n}$ in parentheses.

in treated needles were less than in October, and there was no significant effect of treatment (Figure 3). However, there was a significant effect of concentration on the change in concentration of TCA in needles between October and May with a significant loss of TCA (average $105 \mathrm{ng} \mathrm{g}^{-1} \mathrm{dry}$ wt) from the $100 \mathrm{ng} \mathrm{mL}^{-1}$ treatment (ANOVA, $\mathrm{P}=0.014$ ). There was no difference between soil or foliage application.

Soil: October 1999. Concentrations were determined in cores sampled $26 \mathrm{~d}$ after the last treatment application (Figure 4). Analysis of variance showed a significant interaction between treatment type (soil or foliage) and concentration. Soils where the plant foliage was sprayed but which received no TCA directly had significantly $(P<0.05)$ higher residual concentrations of TCA than soils to which TCA had been directly added during the experiment.

Growth Measurements. No significant effects of the treatment were observed for either absolute or relative changes in plant height, plant root-collar diameter, or stem volume (approximated as a cone). No obvious visible injury was observed that was related to the treatments applied.

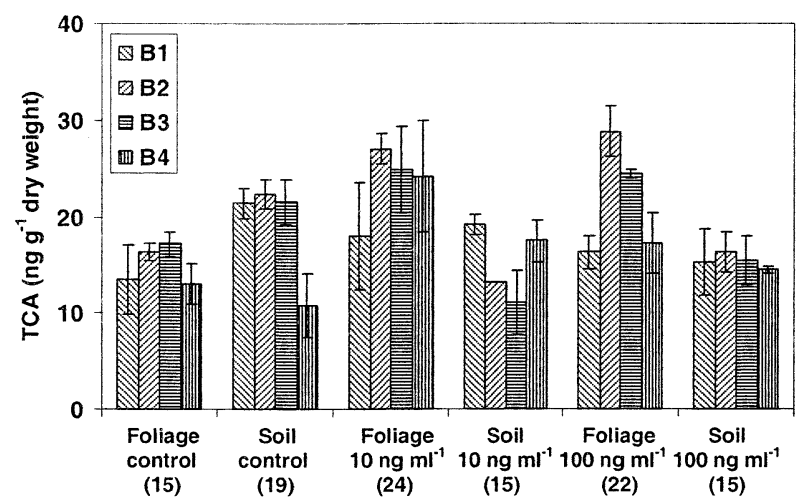

FIGURE 4. Soil content of TCA (ng g ${ }^{-1}$ dry w $\mathrm{t}$ ) in October 1999. Error bars show the standard deviation within each block (B1-B4) of 5 plants. Treatment means are show $n$ in parentheses.

TABLE 3. Needle Content of Protein ( $\mathrm{mg} \mathrm{mL}^{-1}$ Extract) in October 1999a

treatment

height 1 height 2 height 3 height 4 mean

control (foliage)

control (soil)

$\begin{array}{llll}0.19 & 0.30 & 0.32 & 0.17 \\ 0.46 & 0.38 & 0.15 & 0.26\end{array}$

$10 \mathrm{ng} \mathrm{mL}^{-1}$ (foliage) $\quad 0.33 \quad 0.16 \quad 0.14 \quad 0.15$

$\begin{array}{lllll}10 \mathrm{ng} \mathrm{mL}^{-1} \text { (soil) } & 0.19 & 0.28 & 0.38 & 0.09\end{array}$

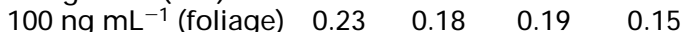

$\begin{array}{lllll}100 \mathrm{ng} \mathrm{mL}^{-1} \text { (soil) } & 0.26 & 0.14 & 0.21 & 0.17\end{array}$

mean

$\begin{array}{llll}0.28^{\mathrm{a}} & 0.24^{\mathrm{ab}} & 0.23^{\mathrm{ab}} & 0.17^{\mathrm{b}}\end{array}$

$0.28^{a}$

$0.21^{\mathrm{ab}}$

$0.19^{b}$

${ }^{a}$ Values with the same superscript are not significantly different $(P=0.05)$.

TABLE 4. Root Content of Protein ( $\mathrm{mg} \mathrm{mL}^{-1}$ Extract) in October 1999a

treatment

height 1 height 2 height 3 height 4 mean

control (foliage)

control (soil)

$\begin{array}{llll}0.20 & 0.24 & 0.31 & 0.15\end{array}$

$\begin{array}{llll}0.42 & 0.36 & 0.14 & 0.24\end{array}$

$\begin{array}{lllll}10 \mathrm{ng} \mathrm{mL}^{-1} \text { (foliage) } & 0.35 & 0.16 & 0.08 & 0.08\end{array}$

$\begin{array}{lllll}10 \mathrm{ng} \mathrm{mL}^{-1} \text { (soil) } & 0.11 & 0.18 & 0.26 & 0.05\end{array}$

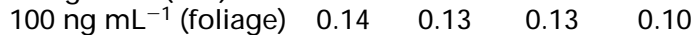

$\begin{array}{lllll}100 \mathrm{ng} \mathrm{mL}^{-1} \text { (soil) } & 0.21 & 0.13 & 0.16 & 0.20\end{array}$

mean

$0.24^{\mathrm{a}} \quad 0.20^{\mathrm{ab}} \quad 0.18^{\mathrm{ab}} \quad 0.14^{\mathrm{b}}$

$0.26^{a}$

$0.16^{\mathrm{b}}$

$0.15^{\mathrm{b}}$

${ }^{a}$ Values with the same superscript are not significantly different $(P=0.05)$.

EnzymeM easurements: October 1999. Initial plant height had a significant effect on protein content in both needle $(P=0.013$, Table 3$)$ and roots $(P=0.021$, Table 4$)$ with larger concentrations in the larger plants. There was also significantly less protein in plants treated with the higher TCA concentration in both needles ( $P=0.011$, Table 3 ) and roots $(P=0.0004$, Table 4) than in the control plants and no significant difference between soil and foliage application. GST activity in needles (using DCNB as a xenobiotic substrate, Table 5) was less in smaller plants $(P=0.003)$ and was significantly greater $(P=0.001)$ in plants that had received a foliar treatment than in those where the treatment was added to the soil. Asthis pattern of response was also observed in the control plants and there was no overall effect of TCA concentrations, it appears that wetting the needles leads to a response in terms of GST activity to DCNB. Expressing the activity relative to the protein content of the needles (i.e., as $\mathrm{nmol}$ of DCNB min $^{-1}$ (mg of protein $)^{-1}$ ) gave no significant effects. No significant differences in the GST enzymeactivity of needles were observed when CDNB was used as the substrate (data not shown), but in roots GST activity (pmol of CDNB $\min ^{-1}$ (mL of extract) ${ }^{-1}$ ) was significantly greater $(P=0.016)$ in larger plants. Relative to protein content, this 
TABLE 5. Needle GST Activity (pmol of DCNB $\mathrm{min}^{-1}$ ( $\mathrm{mL}$ of Extract $\left.)^{-1}\right)^{a}$

\begin{tabular}{|c|c|c|c|c|c|}
\hline treatment & height 1 & neight 2 & height 3 & height 4 & me \\
\hline control (foliage) & 1.2 & 0.7 & 1.2 & 1.9 & \\
\hline control (soil) & 0.7 & 1.2 & 0.6 & 0.6 & \\
\hline $10 \mathrm{ng} \mathrm{mL}^{-1}$ (foliage) & 0.8 & 0.5 & 1.0 & 1.2 & \\
\hline $10 \mathrm{ng} \mathrm{mL}^{-1}$ (soil) & 0.9 & 0.6 & 0.4 & 0.7 & \\
\hline $100 \mathrm{ng} \mathrm{mL}^{-1}$ (foliage) & 3.6 & 0.3 & 0.3 & 0.5 & \\
\hline $100 \mathrm{ng} \mathrm{mL}^{-1}$ (soil) & 0.8 & 0.4 & 0.1 & 0.3 & \\
\hline 19 & $1.3^{\mathrm{a}}$ & $0.6^{b}$ & $0.6^{b}$ & $0.9^{a b}$ & \\
\hline
\end{tabular}

${ }^{a}$ Values with the same superscript are not significantly different $(P=0.05)$.

\section{TABLE 6. Root GST Activity (pmol of CDNB $\mathrm{min}^{-1}$ ( $\mathrm{mg}$ of Protein) $\left.)^{-1}\right)^{a}$}

treatment

height 1 height 2 height 3 height 4 mean

control (foliage)

control (soil)

$10 \mathrm{ng} \mathrm{mL}^{-1}$ (foliage)

$10 \mathrm{ng} \mathrm{mL}^{-1}$ (soil)

$100 \mathrm{ng} \mathrm{mL}^{-1}$ (foliage)

$100 \mathrm{ng} \mathrm{mL}^{-1}$ (soil)

mean

$\begin{array}{llrrr}11 & \text { missing } & 17 & 11 & 13 \\ 14 & 14 & 8 & 8 & 11 \\ 11 & 12 & 4 & 4 & 8 \\ 29 & 23 & 15 & 15 & 20 \\ 20 & 15 & 10 & 6 & 13 \\ 20 & 21 & 17 & 9 & 17 \\ 18^{\mathrm{a}} & 17^{\mathrm{a}} & 12^{\mathrm{ab}} & 9^{\mathrm{b}} & \end{array}$

${ }^{a}$ Values with the same superscript are not significantly different $(P=0.05)$.

pattern was also seen but there was also significantly greater activity $(P=0.023)$ for soil-treated plants than for foliartreated plants (Table 6).

\section{Discussion}

Treatment of Sitka spruce plants with solutions of TCA led to increases in needle concentrations, regardless of whether the treatment was applied to the soil or to the foliage. The overall concentrations in needles were within the range of published values in field-grown coniferous trees, up to 180 ng g $^{-1}$ fresh weight (1). In this study, the needle dry weight was approximately half of the needle fresh weight. The concentrations in thecontrol plantsand the increasebetween August and October probably derive from the presence of TCA in the tap water used for irrigation, which was measured to contain 3-5 ng of TCA $\mathrm{mL}^{-1}$. The amount of TCA added in the irrigation water to each of the saucers in which the pots stood is estimated to be approximately equivalent to that added to the soil surface or to the canopy in the $10 \mathrm{ng}$ $\mathrm{mL}^{-1}$ treatments. The concentration of TCA in tap water was not measured every time plants were irrigated, so the total input through irrigation is not known exactly but was the same for all plants.

The uptake of TCA from both soil and foliage has been demonstrated before, for Scots pine (PinussylvestrisL.) (16), but it was argued that the primary uptake route was via the roots and that concentrations measured in foliage were from external adsorption rather than uptake into the plant. However, this experiment shows that uptake is possible directly from application to the canopy. The measurements are not simply residual TCA on the needle surface because needles were thoroughly rinsed in water before analysis, specifically to remove any residual material. The large concentrations in stem tissue in response to canopy application (Table 2) suggest that the route of entry of TCA may bethrough stems rather than through needles. In a separate experiment, where excised spruce needles were immersed in solutions containing 10 or 100 ng of TCA mL $\mathrm{mL}^{-1}$ for several days, no increase in foliar concentrations was observed (data not shown). However, the concentrations driving transfer from surface water into the foliage will have been much greater as surface water evaporated. Uptake of radiolabeled sulfateions by spruceshoots has been observed (26), showing that pathways for anion uptakeexist for evaporating solutions. Thin water films may also occur on the surface of spruce needles (27), which could act as pathways for the transfer of solutes through stomata.

There was no detectable difference in the rate of uptake by needles between soil and foliar application, even though the above-ground application inevitably led to a smaller overall dose per plant because of the loss of a small quantity of spray that was not intercepted by the canopy during application. The smaller concentrations in the stem tissue as compared to needles of plants where TCA was applied to the soil suggest that needles are the final "sink" for TCA taken up in the transpiration stream, as might be expected. Transport of TCA within a plant occurs rapidly $(13,28)$, at least when roots are exposed to very large concentrations.

The effect of the treatment was still observable in the needles the following spring, 6 months after the treatments ceased. Although some loss of TCA relative to October was noted from the treated needles, this result suggests that the biological degradation of TCA in needles is relatively slow over the winter when the trees are not very active. By contrast, all evidence of TCA additions to soil had disappeared within $26 \mathrm{~d}$ of thelast application, suggesting relatively rapid removal of TCA in soil.

The treatment levels used in this experiment did not lead to visible injury nor to changes in overall plant growth. However, somechanges were observed in theactivity of some enzymes and in the levels of protein found in the needles and roots. The reduction in protein concentrations in plants treated with TCA might be related to the protein-precipitating property of TCA, resulting in a loss of protein from tissue. None of the enzyme responses were attributable to TCA in the treatments, but the significant effect on enzyme activity in needles caused by spraying the plant canopy raises interesting questions over the use of enzyme activity measurements in controlled experiments. In this study, the wetted part of the plants (needle response using DCNB as substrate, roots using CDNB as substrate) showed thegreater levels of enzymeactivity but no response to TCA. These results contrast with the direct effects of TCA on enzyme activity in Scots pine found in earlier work (15), but in that experiment trees were exposed to concentrations of 1 and $50 \mu \mathrm{g} \mathrm{mL}^{-1}$ rather than the 10 and $100 \mathrm{ng} \mathrm{mL}^{-1}$ in this experiment, which were more similar to those that havebeen measured in cloud and rain (Table 7 ).

TABLE 7. Summary of TCA Concentrations in the Environment (1)

\section{precipitation}

$0.1-20\left(\mathrm{ng} \mathrm{mL}^{-1}\right)$

$\begin{array}{ll}\text { Germany } & \left.0.1-20 \mathrm{ng} \mathrm{mL}^{-1}\right) \\ & 0.02-2 \mathrm{ng} \mathrm{mL}^{-1} \text { (cloud; 29) } \\ \text { Canada } & 0-1.6 \mathrm{ng} \mathrm{m}^{-1} \\ \text { Antarctica } & 0.02-0.12 \mathrm{ng} \mathrm{mL}^{-1} \\ \text { Scotland (30, 31) } & 0.13-1.7 \mathrm{ng} \mathrm{mL}^{-1} \text { (rain) } \\ & 0.25-7.2 \mathrm{ng} \mathrm{mL}^{-1} \text { (cloud) }\end{array}$

spruce needles

$$
\text { 4-96 ng g }{ }^{-1} \text { fresh wt }
$$

10-170 ng g ${ }^{-1}$ dry wt (ca. 5-80 $\mathrm{ng} \mathrm{g}^{-1}$ fresh wt) coniferous forest soil
$20-380 \mathrm{ng} \mathrm{g}^{-1}$
$2-12 \mathrm{ng} \mathrm{g}^{-1}$

$20->1000$ ng g $^{-1}$ dry wt 
In conclusion, the 5-month exposure of young spruce trees to TCA at concentrations unlikely to be exceeded in field conditions showed no detectable effects on growth or on visible damage, although protein concentrations were reduced. The experiment has shown that stem uptake of TCA may be important for species where direct leaf uptake is inhibited by leaf surface waxes and may be as important as root uptake for small plants. The breakdown of TCA was also shown to be very much faster in soil than in currentyear spruce needles. It is difficult to extrapolate from this controlled experiment to mature forest trees. Needle concentrations of TCA found in this study with young plants were up to twice those observed in mature Sitka sprucetrees in southern Scotland (Table 7) (31). Although the treatment at $100 \mathrm{ng} \mathrm{mL}^{-1}$ exceeded thelargest measured concentrations in cloud or rainwater, soil concentrations in a Sitka spruce forest have been shown to be very variable with concentrationsnormally $20-50 \mathrm{ng} \mathrm{g}^{-1}$ dry wt but sometimes exceeding $1 \mu \mathrm{g} \mathrm{g}^{-1}$ dry wt (31), which is considerably greater than the amount of TCA added during the treatment $(47 \times 63 \mathrm{~mL} \times$ $100 \mathrm{ng} \mathrm{mL}^{-1}=300 \mu \mathrm{g} \mathrm{pot}^{-1}$, or ca. $50 \mathrm{ng}\left(\mathrm{g}\right.$ of soil) ${ }^{-1}$ ). These results provideinformation on likely pathways of TCA uptake and removal in forest ecosystems and contribute to the continuing debate over the sources of TCA in forests and its relevance to forest health.

\section{Acknowledgments}

This research was funded in part by the U.K. Natural Environmental Research Council's Thematic Programme "Environmental Diagnostics", which provided a studentship for N.M.R. The authors thank EuroChlor for contributing toward the purchase of a headspace autosampler.

\section{Literature Cited}

(1) McCulloch, A. Chemosphere 2002, 47, 667.

(2) Frank, H.; Vincon, A.; Reiss, J.; Scholl, H. J. High Resolut. Chromatogr. 1990, 13, 733 .

(3) Juuti, S.; Hoekstra, E. J. Atmos. Environ. 1998, 32, 3059.

(4) Jordan, A.; Frank, H. Atmos. Environ. 1999, 33, 4525.

(5) Hoekstra, E. J.; Juuti, S. Atmos. Environ. 1999, 33, 4526.

(6) Franklin, J. Toxicol. Environ. Chem. 1994, 46, 169.

(7) Weissflog, L.; Pfennigsdorff, A.; Martinez-Pastur, G.; Puliafito, E.; Figueroa, D.; Elansky, N.; Nikonov, V.; Putz, E.; Kruger, G.; Kellner, K. Atmos. Environ. 2001, 35, 4511.

(8) Haiber, G.; Jacob, G.; Niedan, V.; Nkusi, G.; Scholer, H. F. Chemosphere 1996, 33, 839.
(9) Hoekstra, E. J.; DeLeer, E. W. B.; Brinkman, U. A. T. Chemosphere 1999, 38, 2875.

(10) Forczek, S. T.; Matucha, M.; Uhlirova, H.; Albrechtova, J.; Fuksova, K.; Schroder, H. P. Biol. Plant. 2001, 44, 317.

(11) Haselmann, K. F.; Laturnus, F.; Svensmark, B.; Gron, C. Chemosphere 2000, 41, 1769.

(12) Hafner, C.; Jung, K.; Schuurmann, G. Chemosphere 2002, 46, 259.

(13) Schroll, R.; Bierling, B.; Cao, G.; Dorfler, U.; Lahaniati, M. Langenbach, T.; Scheunert, I.; Winkler, R. Chemosphere 1994, 28, 297.

(14) Juuti, S.; Norokorpi, Y.; Ruuskanen, J. Chemosphere 1995, 30, 439.

(15) Schröder, P.; Juuti, S.; Roy, S.; Sandermann, H.; Sutinen, S. Environ. Sci. Pollut. Res. 1997, 4, 163.

(16) Sutinen, S.; Juuti, S.; Koivisto, L.; Turunen, M.; Ruuskanen, J. J. Exp. Bot. 1995, 46, 1223.

(17) Norokorpi, Y.; Frank, H. Sci. Total Environ. 1995, 161, 459.

(18) Frank, H.; Scholl, H.; Sutinen, S.; Norokorpi, Y. Ann. Bot. Fenn. 1992, 29, 263.

(19) Juuti, S.; Norokorpi, Y.; Helle, T.; Ruuskanen, J. Sci. Total Environ. 1996, 180, 117.

(20) Garrec, J. P.; Henry, C.; Lemaout, L. Environ. Exp. Bot. 1995, 35 399.

(21) Sutinen, S.; Juuti, S.; Ryyppö, A. Ann. Bot. Fenn. 1997, 34, 265.

(22) Plümacher, J.; Renner, I. Fresenius J. Anal. Chem. 1993, 347, 129.

(23) Schröder, P.; Berkau, C. Bot. Acta 1993, 106, 301.

(24) Schröder, P.; Rusness, D. G.; Lamoureux, G. L.; Rennenberg, H. Pestic. Biochem. Physiol. 1990, 37, 211.

(25) Bradford, M. M. Anal. Biochem. 1976, 72, 248.

(26) Percy, K. E.; Baker, E. A. In Air Pollution and Forest Decline (Proceedings of the 14th International Meeting for Specialists in Air Pollution Effects on Forest Ecosystems IUFO P2.05); Bucher, J. B., Bucher-Wallin, I., Eds.; EAFV Birmensdorf: Interlaken, Switzerland, 1989; pp 493-495.

(27) Burkhardt, J.; Eiden, R. Atmos. Environ. 1994, 28, 2001.

(28) Uhlirova, H.; Matucha, M.; Kretschmar, M.; Bubner, M. UWSFZ. Umweltchem. Ökotox. 1996, 8, 138.

(29) Römpp, A.; Klemm, O.; Fricke, W.; Frank, H. Environ. Sci. Technol. 2001, 35, 1294

(30) Heal, M. R.; Reeves, N.; Cape, J. N. Environ. Sci. Technol. 2003, 37, 2627-2633.

(31) Reeves, N. Ph.D. Dissertation, University of Edinburgh, 2001.

Received for review February 3, 2003. Revised manuscript received April 9, 2003. Accepted April 22, 2003.

ESO34094Z 